\title{
KOMPOSISI JENIS DAN STRUKTUR TEGAKAN BERBAGAI FORMASI HUTAN DI RESORT BAMA TAMAN NASIONAL BALURAN, JAWA TIMUR
}

\author{
Composition of Types and Structures Establish Various Forest Formations at Bama Resort \\ Baluran National Park, East Java
}

\author{
Istomo $^{1^{*}}$ dan Wahyu Hartarto ${ }^{1}$
}

(Diterima Juni 2019/ Disetujui Agustus 2019)

\begin{abstract}
Baluran National Park is a oldes national park and unique in terms of existing ecosystems. One area that is considered to be of broad condition is Bama Resort. Baluran National Park has various forest formations including mangrove formations, coastal forests, savana forests, seasonal forests, rainforests, and plain forests. This study aims to examine the composition and structure of each forest formation in Baluran National Park in East Java. The number of plant species found in mangrove forest formations were 6 species, 40 species of coastal forest, 37 species of savana forest, 44 species of rain forest, 28 species of lowland forest, and 50 species of seasonal forest formations. The highest density values were in savana forest formation at the seedlings and understorey level of 132445 ind / ha while the density at the tree level was found in the mangrove forest formation of 346 ind / ha. The diversity index of seedlings and understorey species is medium $\left(2<H^{\prime}<3\right)$ while for other growth rates it is classified as medium and low $\left(0<H^{\prime}<3\right)$. The value of community similarity between overall forest formations is categorized as low (values below 50\%.). Overall header stratification in each formation is in strata $c$.
\end{abstract}

Key words: Forest Formation, Species Composition, Structure, Baluran National Park

\section{PENDAHULUAN}

Hutan adalah hamparan lahan yang berisi komunitas tumbuhan yang didominasi oleh pohon-pohon dan saling berinteraksi satu sama lain. Menurut Soerianegara dan Indrawan (2002) hutan adalah ekosistem yang dicirikan oleh komunitas pohon dan sumberdaya alam hayati lainnya yang pengelolaan dan pelestariannya memerlukan pengetahuan ekologi dan pendekatan ekosistem. Suatu ekosistem hutan akan memiliki hubungan yang erat antara vegetasi yang tumbuh dengan kondisi lingkungannya. Hubungan ini terlihat dengan adanya variasi dalam jumlah masingmasing jenis tumbuhan dan terbentuknya struktur tumbuh-tumbuhan tersebut. Terbentuknya pola keanekaragaman dan struktur tegakan hutan merupakan proses yang dinamis, erat hubungannya dengan kondisi lingkungan, baik biotik maupun abiotik.

Salah satu wilayah yang memiliki keanekaragaman jenis yang tinggi dengan formasi hutan yang unik adalah Taman Nasional Baluran. Tipe ekosistem yang berada di Taman Nasional Baluran meliputi hutan pantai, hutan bakau/mangrove, hutan savana (padang rumput alami), hutan selalu hijau (evergreen), hutan musim dataran rendah, dan hutan musim pegunungan. Taman Nasional Baluran memiliki karakteristik khusus dengan bentangan savana, namun kondisinya saat ini telah

\footnotetext{
Departemen Silvikultur, Fakultas Kehutanan IPB University

*Penulis korespondensi:

E-mail: istomo19@gmail.com
}

banyak mengalami tekanan dan gangguan yang dapat mempengaruhi fungsi Taman Nasional Baluran sebagai wilayah konservasi sumber daya. Penelitian ini bertujuan mengkaji komposisi dan struktur tiap formasi hutan di Taman Nasional Baluran Jawa Timur.

\section{METODE PENELITIAN}

\section{Waktu dan Tempat Penelitian}

Penelitian ini dilaksanakan pada tanggal 17 Januari 2017 sampai 1 Januari 2018. Pengambilan data dilaksanakan pada formasi hutan mangrove, hutan pantai, hutan savana, hutan hujan, hutan musim, hutan dataran rendah di hutan Resort Bama TN Baluran Situbondo, Jawa Tiinur. Pembuatan herbarium dan identifikasi jenis tumbuhan dilakukan di Laboratorium Ekologi Hutan, Departemen Silvikultur, Fakultas Kehutanan IPB.

\section{Alat dan Bahan}

Peralatan yang digunakan adalah GPS, kompas, peta kawasan, golok, pita ukur, pita tagging, patok, haga hypsometer, meteran jahit, tally sheet, alat tulis, Lutron 4 in 1 (termometer, luxmeter, dan higrometer), kamera, peralatan herbarium (kertas koran, label, gunting, alkohol $70 \%$, plastik bening berukuran $20 \mathrm{~kg}$, sasak, tali rafia, oven) dan buku identifikasi jenis. Bahan untuk penelitian yaitu vegetasi berbagai formasi hutan di Resort Bama TN Baluran. 


\section{Pembuatan Petak Pengamatan}

Petak contoh dibuat dengan mengkombinasikan metode jalur transek dan garis berpetak yang memotong garis kontur. Penempatan petak contoh berada pada dua lokasi yaitu ketinggian 800 mdpl dan 1200 mdpl dengan masing-masing terdapat dua jalur, setiap jalur memiliki ukuran 20 × $500 \mathrm{~m}$. Analisis vegetasi tingkat pohon dilakukan pada sub petak ukuran 20 × $20 \mathrm{~m}$ (A), tingkat tiang berukuran $10 \times 10 \mathrm{~m}$ (B), tingkat pancang berukuran $5 \times 5 \mathrm{~m}(\mathrm{C})$, tingkat semai berukuran $2 \times 2 \mathrm{~m}$ (D).

\section{Analisis Data}

\section{Indeks Nilai Penting (INP)}

INP adalah parameter kuantitatif yang menunjukkan dominansi suatu jenis, dihitung dengan menggunakan rumus Mueller-Dumbois dan Ellenberg (1974) :

Kerapatan $(\mathrm{K})=\frac{\text { Jumlah individu suatu jenis }(N)}{\text { Luas petak contoh }(h a)}$

Kerapatan Relatif $(\mathrm{KR})=\frac{\text { Kerapatan suatu jenis }}{\text { Kerapatan seluruh jenis }} \times 100$

Frekuensi $(\mathrm{F})=\frac{\text { Jumlah } \text { plot ditemukan suatu jenis }}{\text { Jumlah seluruh plot }}$

Frekuensi Relatif $(\mathrm{FR})=\frac{\text { Frekuensi suatu jenis }}{\text { Frekuensi seluruh jenis }} \times 100$

Dominansi $(\mathrm{D})=\frac{\text { Jumlah bidang dasar suatu jenis }}{\text { Luas petak contoh }(\mathrm{ha})}$

Dominansi Relatif $(\mathrm{DR})=\frac{\text { Dominansi suatu jenis }}{\text { Dominansi seluruh jenis }} \times 100$

INP $(\%)=\mathrm{KR}+\mathrm{FR}$ (untuk tingkat semai dan pancang) $\mathrm{INP}(\%)=\mathrm{KR}+\mathrm{FR}+\mathrm{DR}$ (untuk tingkat tiang dan pohon)

\section{Indeks Dominansi Jenis (C)}

Indeks Dominansi jenis merupakan perhitungan untuk mengetahui penguasaan suatu jenis pada suatu komunitas. Indeks dominansi dihitung menggunakan rumus Margalef (Indriyanto 2012) yaitu:

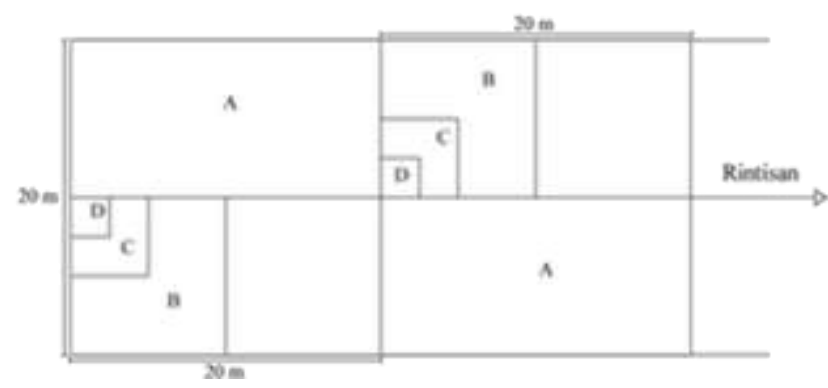

Gambar 1 Desain petak contoh dengan menggunakan metode kombinasi (Kusmana 1997)

$$
C=\sum_{i=1}^{n}\left(\frac{n i}{N}\right)^{2}
$$

Keterangan:

$\mathrm{C} \quad=$ Indeks Dominansi Jenis

ni = Jumlah individu jenis ke-i

$\mathrm{N}=$ Total individu

\section{Indeks Keanekaragaman Jenis (H')}

Analisis Indeks Keanekaragaman Jenis (H') dihitung menggunakan rumus keanekaragaman jenis Shannon Diversity Indeks (Magurran 1988) :

$$
H^{\prime}=-\sum_{i=1}^{n}\left[\left(\frac{n i}{N}\right) \ln \left[\left(\frac{n i}{N}\right)\right]\right.
$$

Keterangan:

H' = Indeks Keanekaragaman Jenis Shannon

$\mathrm{Ni}=$ Jumlah individu jenis ke-i

$\mathrm{N}=$ Total individu seluruh jenis

\section{Indeks Kekayaan Jenis (R)}

Indeks Kekayaan jenis dihitung menggunakan rumus Margallef (Magurran 1988) :

Keterangan:

$$
R=\frac{(S-1)}{\ln (N)}
$$

$\mathrm{R} \quad=$ Indeks Kekayaan Jenis

$\mathrm{S} \quad=$ Jumlah jenis yang ditemukan

$\mathrm{N}=$ Jumlah total individu

\section{Indeks Kemerataan Jenis (E)}

Indeks Kemerataan Jenis (E) menunjukkan tingkat kemerataan individu per jenis dalam suatu area. Nilai E dihitung menggunakan rumus (Magurran 1988):

Keterangan:

$$
\mathrm{E}=\frac{H^{\prime}}{\ln (S)}
$$

$\mathrm{E} \quad=$ Indeks kemerataan jenis

$\mathrm{H}^{\prime}$ = Indeks keanekaragaman jenis

Ln = Logaritma natural

$\mathrm{S} \quad=$ Jumlah spesies

\section{Indeks Kesamaan Komunitas}

Indeks kesamaan komunitas digunakan untuk mengetahui tingkat kesamaan komunitas tumbuhan dari dua tegakan yang dibandingkan pada setiap tingkat pertumbuhan. Nilai IS yang dapat digunakan sebagai berikut (Mueller-Dumbois dan Ellenberg 1974):

$$
\text { IS }=\frac{2 W}{a+b}
$$

Keterangan:

IS $=$ indeks kesamaan komunitas

$\mathrm{W}=$ jumlah dari nilai penting yang lebih kecil atau sama dari dua spesies yang berpasangan, yang 
ditemukan pada dua komunitas

$\mathrm{a}=$ jumlah INP dari semua jenis yang terdapat pada komunitas A

$\mathrm{b}=$ jumlah INP dari semua jenis yang terdapat pada komunitas $\mathrm{B}$

\section{KONDISI UMUM PENELITIAN}

Kawasan TN Baluran terletak di Kecamatan Banyuputih, Kabupaten Situbondo, Propinsi Jawa Timur. Berdasarkan SK. Menteri Kehutanan No. 279/Kpts.-VI/1997 tanggal 23 Mei 1997 kawasan TN Baluran memiliki areal seluas 25.000 ha. Sesuai dengan peruntukkannya luas kawasan tersebut dibagi menjadi beberapa zona berdasarkan SK. Dirjen PKA No. 187/Kpts./DJ-V/1999 tanggal 13 Desember 1999 yang terdiri dari: zona inti seluas 12.000 ha, zona rimba seluas 5.537 ha (perairan $=1.063$ ha dan daratan $=4.574$ ha), zona pemanfaatan intensif dengan luas 800 ha, zona pemanfaatan khusus dengan luas 5.780 ha, dan zona rehabilitasi seluas 783 ha. sementara dari segi pengelolaan kawasan TN Baluran dibagi menjadi dua Seksi Pengelolaan Taman Nasional, yaitu: Seksi Pengelolaan Taman Nasional Wilayah I Bekol, meliputi Resort Bama, Balanan dan Perengan, Seksi Pengelolaan Taman Nasional Wilayah II Karangtekok meliputi Resort Watu Numpuk, Labuhan Merak dan Bitakol. Kawasan Taman Nasional Baluran termasuk daerah yang beriklim kering dengan tipe curah hujan F (tipe curah hujan menurut Schmidt dan Ferguson) dengan temperatur berkisar antara $27.2^{\circ} \mathrm{C}-30.9^{\circ} \mathrm{C}$, kelembapan udara $77 \%$, kecepatan angin 7 Knots, dari landai sampai bergunung- Taman Nasional Baluran mempunyai bentuk topografi yang bervariasi gunung dan mempunyai ketinggian berkisar antara 0-1247 mdpl. Tipe ekosistem tersebut meliputi hutan pantai, mangrove, hutan savana (padang rumput alami), hutan selalu hijau (evergreen), hutan musim dataran rendah, dan hutan musim pegunungan.

\section{HASIL DAN PEMBAHASAN}

\section{Komposisi Jenis Tumbuhan}

Keragaman jenis tumbuhan tertinggi berbagai formasi hutan dibaluran berada di hutan hujan yaitu sebanyak 44 jenis. Berdasarkan tingkat pertumbuhannya, tingkat semai dan tumbuhan bawah memiliki jumlah keragaman jenis yang tertinggi secara merata disetiap formasi hutan yang lain. Jumlah jenis tumbuhan terbanyak pada tingkat semai dan tumbuhan terdapat pada formasi hutan savana sebanyak 32 jenis, pada tingkat pancang terdapat pada formasi hutan musim sebanyak 10 jenis, pada tingkat tiang terdapat pada formasi hutan musim sebanyak 6 jenis, dan pada tingkat pohon terdapat pada formasi hutan hujan sebesar 16 jenis. Perbedaan komposisi tersebut disajikan lebih jelas pada Tabel 3. Beberapa faktor yang memengaruhi keragaman pada suatu komunitas yaitu jarak geografis dan intensitas curah hujan yang tinggi. Keragaman jenis yang sangat rendah berada di Formasi Hutan Mangrove dikarenakan sangat mendominasinya jenis Rhizophora apiculata dan Rhizophora stylosa setiap tingkat pertumbuhannya. Jumlah komposisi jenis berbagai formasi hutan disajikan pada Tabel 1.

\section{Indeks Nilai Penting (INP)}

Peranan suatu jenis dalam sebuah komunitas dapat dilihat dari besarnya nilai INP. Tingginya indeks nilai penting suatu jenis disebabkan oleh kerapatan yang besar dan persebarannya merata pada seluruh areal. Kusmana dan Susanti (2015), menjelaskan bahwa dominannya suatu jenis tumbuhan disebabkan oleh kemampuannya dalam memanfaatkan sumberdaya yang ada dibandingkan dengan jenis-jenis yang lain. Berdasarkan hasil perhitungan INP (Lampiran 1), formasi hutan mangrove di dominasi oleh jenis Rhizophora stylosa pada tingkat pancang sebesar $81.03 \%$ dan tingkat pohon oleh jenis Rhizophora apiculata sebesar $216.35 \%$.

Kondisi formasi hutan mangrove di Resort Bama TN Baluran termasuk kedalam jenis mangrove yang sering tergenang. Menurut Aksornkoae (1993) bahwa $R$. mucronata dan $R$. apiculata lebih suka berada pada daerah dengan pasang tinggi (selalu tergenang). Fenomena ini sama seperti di kawasan hutan mangrove Desa Tanjung Sekodi Kabupaten Bengkalis, Provinsi Riau, baik pada strata pohon, tiang, sapihan dan semai didominasi $R$. apiculata (Nursal et al. 2005). Menurut Tomlinson (1986) jenis-jenis tersebut ( $R$. mucronata, $R$. apiculata, $R$. stylosa) termasuk kategori takson spesifik mangrove (true mangroves), yang hanya ditemukan di ekosistem mangrove pada umumnya.

Formasi hutan pantai, jenis yang mendominasi tertinggi berada pada tingkat tiang jenis Grewia eriocarpa sebesar $110.00 \%$. Tingkat pohon dominasi terbesar berada pada jenis Salmalia veletonii sebesar $70.51 \%$. Nilai INP ini tergolong rendah dikarenakan lokasi hutan pantai memiliki luasan yang lebih sedikit dan berada diantara formasi hutan mangrove dan hutan savana. Formasi hutan Pantai ditemukan jenis Terminallia catappa yang berukuran raksasa dan berusia tua. Hal ini memperlihatkan penyerapan nutrisi yang tidak seimbang.

Tabel 1 Komposisi jenis tumbuhan berbagai formasi hutan

\begin{tabular}{lcccccc}
\hline & \multicolumn{5}{c}{ Formasi Hutan } \\
\cline { 2 - 6 } Tingkat Pertumbuhan & $\begin{array}{c}\text { Hutan } \\
\text { Mangrove }\end{array}$ & $\begin{array}{c}\text { Hutan } \\
\text { Pantai }\end{array}$ & $\begin{array}{c}\text { Hutan } \\
\text { Savana }\end{array}$ & $\begin{array}{c}\text { Hutan } \\
\text { Hujan }\end{array}$ & $\begin{array}{c}\text { Hutan } \\
\text { Musim }\end{array}$ & $\begin{array}{c}\text { Hutan Dataran } \\
\text { Rendah }\end{array}$ \\
\hline Semai dan tumbuhan & 0 & 17 & 32 & 17 & 28 \\
Bawah & & 7 & 1 & 7 & 10 \\
Pancang & 4 & 5 & 2 & 4 & 6 \\
Tiang & - & 11 & 2 & 16 & 6 \\
Pohon & 2 & & 5 & 5 \\
\hline
\end{tabular}


Formasi hutan savana memiliki kondisi kerapatan tegakkan yang rendah dan didominasi oleh rerumputan dan tumbuhan bawah. INP yang didapatkan Jenis Ziziphus mauritiana memiliki dominasi yang tinggi khusus nya pada tingkat pancang.

Zizphus mauritiana sangat mendominasi di tingkat pancang karna tidak ada jenis lain yang ditemukan pada plot sampling yang diambil. Tingkat pohon, jenis Ziziphus mauritian juga menjadi jenis yang mendominasi dengan nilai INP mencapai $269.67 \%$.

Formasi hutan hujan, jenis yang mendominasi yaitu jenis streblus asper khususnya pada tingkat tiang dan pohon yang memiliki nilai masing-masing sebesar $101.12 \%$ dan $153.24 \%$. Hal ini terjadi karena kondisi hutan hujan di TN Baluran tetap hijau meski mengalami musim kemarau yang panjang berbeda dengan formasi hutan lainya yang mengalami kekeringan ketika musim kemarau tiba.

Formasi hutan musim jenis Schouthenia ovate memiliki nilai dominasi yang kuat, dimulai dari tingkat pancang (48.20\%), tiang (179.14) sedangkan untuk tingkat pohon Jenis Tamarindus Indica yang memiliki dominansi yang kuat dengan nilai sebesar 79\%. Jenis dominaan pada formasi hutan tidak cukup beragam akibat perubahan musim yang akan sangat berpengaruh terhadap kondisi formasi hutan ini.

Jenis grewia eriocarpa memiliki dominasi yang kuat pada formasi hutan pantai khususnya pada tingkat tiang sebesar $160.55 \%$ dan pohon sebesar $145.54 \%$. Jenis ini sama dengan jenis yang mendominasi di formasi hutan pantai. Tingginya aktifitas satwa liar memengaruhi proses penyebaran jenis tersebut.

\section{Indeks Dominansi Jenis}

Berdasarkan hasil yang didapatkan (Tabel 2), nilai indeks dominansi pada setiap formasi hutan tergolong rendah karena nilai yang didapatkan cenderung mendekati nol kecuali pada formasi hutan savana pada tingkat tiang pancang dan pohon yang memiliki nilai masing-masing sebesar 1.00 pada tingkat pancang dan 0.82 pada tingkat pohon. Hal ini menunjukkan bahwa pada setiap tingkat pertumbuhan dan tumbuhan bawah di berbagai formasi hutan tidak dikuasai oleh satu spesies tumbuhan, tetapi dikuasai secara bersama-sama. Keanekaragaman jenis pada hutan alam pada umumnya lebih tinggi sehingga nilai Indeks Dominansinya rendah. Hal ini yang mengindikasi kestabilan suatu habitat. Fenomena ini merupakan gambaran dari hutan tropis

Tabel 2 Nilai indeks dominansi jenis

\begin{tabular}{lcccc}
\hline Formasi Hutan & \multicolumn{4}{c}{ Tingkat Pertumbuhan } \\
\cline { 2 - 5 } & $\begin{array}{c}\text { Semai \& } \\
\text { tumbuhan } \\
\text { bawah }\end{array}$ & Pancang & Tiang & Pohon \\
& 0.00 & 0.32 & 0.00 & 0.60 \\
Hutan & 0.10 & 0.33 & 0.26 & 0.15 \\
mangrove & 0.06 & 1.00 & 0.51 & 0.82 \\
Hutan pantai & 0.10 & 0.19 & 0.29 & 0.30 \\
Hutan savana & 0.09 & 0.16 & 0.40 & 0.19 \\
$\begin{array}{l}\text { Hutan hujan } \\
\text { Hutan musim }\end{array}$ & 0.11 & 0.54 & 0.35 & 0.33 \\
$\begin{array}{l}\text { Hutan dataran } \\
\text { rendah }\end{array}$ & & & & \\
\hline
\end{tabular}

meskipun pada hutan yang telah terganggu (Mulyana et al. 2017).

\section{Indeks keanekaragaman jenis (H')}

Berdasarkan data yang disajikan dalam Tabel 3, diketahui bahwa indeks keanekaragaman jenis untuk semai dan tumbuhan bawah tergolong sedang $\left(2<\mathrm{H}^{\prime}<\right.$ 3) sedangkan untuk tingkat pertumbuhan lainya disetiap formasi hutan tergolong dalam ketegori rendah dan sedang. Suatu komunitas akan cenderung stabil dan lebih tangguh menghadapi gangguan hutan dengan semakin tingginya keanekargaman jenis yang ada dalam komunitas tersebut (Irwan 2009). Nilai H' tertinggi untuk semai dan tumbuhan bawah terdapat pada formasi hutan savana. Tingkat pancang Nilai H' tertinggi terdapat pada formasi hutan musim sebesar 2.03. Faktor yang sangat memengaruhi Nilai $H^{\prime}$ ini adalah kelimpahan jenis dan kemerataan jenis (Mulyasana 2008). Hal ini yang membuat semakin banyak jenis dan jumlah individu yang merata pada setiap jenisnya, akan membuat nilai indeks keanekaragaman yang didapatkan semakin tinggi.

\section{Indeks kekayaan Jenis (R')}

Formasi hutan yang memiliki nilai kekayaan jenis (R) yang tinggi setiap tingkat pertumbuhanya adalah formasi hutan musim, dilihat dari nilai $\mathrm{R}$ yang memiliki nilai diatas 5 atau dikategorikan tinggi. Habitus tumbuhan bawah dan semai di semua formasi hutan memiliki tingkat kekayaan jenis yang paling tinggi dibandingkan tingkat pertumbuhan lainnya yaitu berkisar antara 13.82-31.87 dengan nilai kekayaan jenis tertinggi di formasi hutan Musim (Tabel 4).

\section{Indeks kemerataan Jenis (E)}

Nilai indeks Kemerataan (E) yang diperoleh pada semua formasi hutan di setiap tingkat pertumbuhannya tergolong tinggi kecuali pada hutan savana pada tingkat pancang dan pohon (Tabel 5). Nilai indeks Kemerataan yang tinggi menunjukkan bahwa hampir seluruh jenis pada setiap tingkat pertumbuhan dan tumbuhan bawah di berbagai ketinggian memiliki jumlah individu yang merata sedangkan kemerataan yang rendah pada formasi hutan savana tergolong wajar dikarenakan jumlah jenis

Tabel 3 Nilai indeks keanekaragaman (H')

\begin{tabular}{lllll}
\hline & \multicolumn{4}{c}{ Tingkat Pertumbuhan } \\
\cline { 2 - 5 } Formasi Hutan & $\begin{array}{c}\text { Semai \& } \\
\text { tumbuhan } \\
\text { bawah }\end{array}$ & Pancang & Tiang & Pohon \\
\hline Hutan & 0.00 & 1.24 & 0.00 & 0.59 \\
mangrove & & 1.46 & 1.47 & 2.12 \\
Hutan pantai & 2.49 & 0.00 & 0.69 & 0.33 \\
Hutan savana & 2.95 & 1.82 & 1.29 & 1.80 \\
Hutan hujan & 2.53 & 2.03 & 1.27 & 1.72 \\
Hutan musim & 2.76 & 0.81 & 1.29 & 1.30 \\
$\begin{array}{l}\text { Hutan dataran } \\
\text { rendah }\end{array}$ & 2.37 & & & \\
\hline
\end{tabular}


yang ditemukan lebih sedikit, sehingga akan memengaruhi besarnya nilai. Ludwig \& Reynold (1988) menyatakan bahwa nilai Indeks Kemerataan Jenis akan berubah secara signifikan jika ada penambahan jenis terutama yang memiliki individu yang rendah dalam suatu komunitas.

\section{Indeks Kesamaan Komunitas (IS)}

Berdasarkan Tabel 6 komposisi jenis pada setiap tingkat pertumbuhan dan tumbuhan bawah di berbagai formasi hutan tergolong rendah karena memiliki nilai indeks kesamaaan komunitas (IS) berkisar antara 1.62$30.71 \%$. Fenomena ini sesuai dengan pernyataan Soerianegara \& Indrawan (2002) yang mengatakan bahwa hutan hujan tropika memiliki keragaman jenis yang tinggi pada tingkat spesies sehingga menyebabkan penyusun dalam komunitas menjadi kompleks dan beragam. Penyebab perbedaan komposisi jenis pada suatu komunitas bisa dipengaruhi faktor kondisi lingkungan yang berbeda (suhu, kelembapan, topografi, dan tanah) dan adanya gangguan hutan. Komponen struktur vegetasi dibagi menjadi tiga, yaitu struktur vertikal (yaitu stratifikasi menjadi beberapa lapisan), struktur horizontal (yaitu sebaran populasi dan individu jenis menurut ruang) dan struktur kuantitatif (yaitu kelimpahan setiap jenis dalam komunitas.

Tabel 4 Nilai indeks kekayaan (R)

\begin{tabular}{lcccr}
\hline \multirow{4}{*}{$\begin{array}{c}c \\
\text { Formasi }\end{array}$} & \multicolumn{4}{c}{ Tingkat Pertumbuhan } \\
\cline { 2 - 5 } & $\begin{array}{c}\text { Semai \& } \\
\text { tumbuhan } \\
\text { Bawah }\end{array}$ & Pancang & Tiang & Pohon \\
\hline Hutan & 0.00 & 3.73 & 0.00 & 1.74 \\
Mangrove & 16.80 & 6.73 & 4.52 & 10.70 \\
Hutan Pantai & 31.87 & 0.00 & 1.49 & 1.52 \\
Hutan Savana & 16.79 & 6.67 & 3.59 & 15.75 \\
Hutan Hujan & 27.85 & 9.72 & 5.69 & 5.70 \\
Hutan Musim & 13.82 & 2.52 & 4.57 & 4.73 \\
Hutan Dataran & & & & \\
Rendah &
\end{tabular}

\section{Struktur Tegakan}

Berdasarkan data dalam Tabel 7, kerapatan individu semakin menurun dengan meningkatnya tingkat perumbuhan kecuali pada formasi hutan mangrove. Nilai Kerapatan tertinggi berada pada formasi hutan savana sebesar 132.445 batang/ha. Sementara untuk kerapatan semai dan tumbuhan bawah yang terendah terdapat pada formasi hutan mangrove. Kerapatan tertingi untuk tingkat panjang terdapat pada formasi hutan pantai sedangkan kerapatan pancang terendah terdapat pada formasi savana. Kerapatan tertinggi untuk tingkat tiang terdapat pada formasi hutan musim sedangkan kerapatan tiang terendah terdapat pada formasi hutan savana. Kerapatan tertinggi untuk tingkat pohon terdapat pada formasi hutan mangrove sedangkan kerapatan pohon terendah terdapat pada formasi hutan savana.

\section{Struktur Horizontal}

Struktur horizontal dari suatu tegakan dapat dilihat dari hubungan kerapatan pohon dengan sebaran kelas diameternya. Berdasarkan Gambar 2, Kerapatan pohon tertinggi berbagai formasi hutan terdapat pada kelas diameter 20-40 cm, semakin besar ukuran diameter pohon, semakin menurun kerapatannya. Seiring

Tabel 5 Nilai indeks kemerataan (E)

\begin{tabular}{lllll}
\hline \multirow{2}{*}{$\begin{array}{c}\text { Formasi } \\
\text { Hutan }\end{array}$} & $\begin{array}{c}\text { Semai \& } \\
\text { tumbuhan } \\
\text { Bawah }\end{array}$ & Pancang & Tiang & Pohon \\
\hline $\begin{array}{l}\text { Hutan } \\
\text { Mangrove }\end{array}$ & 0 & 0.89 & 0 & 0.85 \\
Hutan Pantai & 0.88 & 0.75 & 0.91 & 0.88 \\
Hutan Savana & 0.85 & 0 & 0.99 & 0.47 \\
Hutan Hujan & 0.90 & 0.94 & 0.93 & 0.65 \\
Hutan Musim & 0.83 & 0.88 & 0.70 & 0.96 \\
Hutan Dataran & 0.90 & 0.73 & 0.80 & 0.81 \\
Rendah & & & & \\
\hline
\end{tabular}

Tabel 6 Indeks kesamaan komunitas

\begin{tabular}{|c|c|c|c|c|c|c|}
\hline & \multicolumn{6}{|c|}{ Indeks Kesamaan Komunitas (\%) } \\
\hline & $\begin{array}{c}\text { Hutan } \\
\text { mangrove }\end{array}$ & $\begin{array}{l}\text { Hutan } \\
\text { pantai }\end{array}$ & $\begin{array}{l}\text { Hutan } \\
\text { savana }\end{array}$ & Hutan Hujan & Hutan musim & $\begin{array}{c}\text { Hutan Dataran } \\
\text { Rendah }\end{array}$ \\
\hline Hutan mangrove & 100 & & & & & \\
\hline Hutan Pantai & 0 & 100 & & & & \\
\hline Hutan Savana & 0 & 0 & 100 & & & \\
\hline Hutan Hujan & 0 & 0 & 0 & 100 & & \\
\hline Hutan Musim & 0 & 17.30 & 0 & 1.62 & 100 & \\
\hline $\begin{array}{l}\text { Hutan Dataran } \\
\text { rendah }\end{array}$ & 0 & 17.30 & 0 & 1.62 & 30.71 & 100 \\
\hline
\end{tabular}

Tabel 7 Kerapatan pohon berbagai formasi hutan

\begin{tabular}{lccrrrr}
\hline & & \multicolumn{4}{c}{ Ekosistem (Ind/ha) } \\
\cline { 2 - 6 } Tingkat Pertumbuhan & $\begin{array}{c}\text { Hutan } \\
\text { mangrove }\end{array}$ & $\begin{array}{c}\text { Hutan } \\
\text { pantai }\end{array}$ & $\begin{array}{c}\text { Hutan } \\
\text { savana }\end{array}$ & $\begin{array}{c}\text { Hutan Hujan } \\
\text { Hutan } \\
\text { musim }\end{array}$ & $\begin{array}{c}\text { Hutan Dataran } \\
\text { Rendah }\end{array}$ \\
\hline Semai dan tumbuhan & 0 & 9556 & 132445 & 7000 & 41661 \\
Pancang & 108 & 374 & 9 & 178 & 18945 \\
Tiang & - & 18 & 16 & 30 & 56 \\
Pohon & 346 & 15 & 5 & 23 & 14 \\
\hline
\end{tabular}


bertambahnya ukuran diameter pohon, semakin sedikit ditemukannya jumlah pohon yang tersebar pada kelas diameter tersebut (Oladoye et al. 2014). Kerapatan terendah terdapat pada kelas diameter $>60 \mathrm{~cm}$. Kerapatan individu di berbagai formasi hutan menurun seiring dengan meningkatnya tingkat pertumbuhan (Hilwan 2012).

Kurva yang dihasilkan pada Gambar 2 membentuk kurva $\mathbf{J}$ terbalik kecuali pada formasi hutan mangrove. Namun kondisi ini berbeda dengan kondisi formasi hutan mangrove, dikarenakan tidak adanya semai yang ditemukan akibat kondisi tegakkan yang sudah memasuki fase klimaks dan cukup rapat.

\section{Struktur Vertikal}

Struktur tegakan vertikal dapat dilihat dari hubungan kerapatan pohon dengan tinggi kanopinya. Pembagian kelas tinggi dilakukan dengan mengikuti strata pohon Menurut Soerianegara dan Indrawan (2002), stratum A dengan tinggi pohon $>30 \mathrm{~m}$, stratum B dengan tinggi pohon 20-30 $\mathrm{m}$ dan stratum $\mathrm{C}$ dengan tinggi pohon 4-20 m. Berdasarkan Gambar 3, pohon pada kelas tinggi 4-20 $\mathrm{m}$ memiliki kerapatan tertinggi pada berbagai formasi hutan. Kerapatan pohon semakin menurun seiring dengan meningkatnya kelas tinggi pohon. Menurunnya kerapatan seiring dengan meningkatnya tingkat pertumbuhan yang menunjukkan bahwa individu tertentu tidak seluruhnya tumbuh ke tingkat pertumbuhan berikutnya.

Ciri-ciri pohon pada stratum $\mathrm{C}$ memiliki tajuk yang kontinyu, pohonnya rendah, kecil, dan banyak cabang (Soerianegara dan Indrawan 2016). Stratifikasi tajuk ini terjadi karena dua hal penting yang dialami oleh tumbuhan dalam persekutuan hidupnya dengan tumbuhan lainnya yaitu adanya persaingan antar tumbuhan dan akibat sifat toleransi spesies pohon terhadap intensitas radiasi matahari (Indriyanto 2012).

Jumlah luas bidang dasar (LBDS) untuk tingkat pohon dan tiang di setiap formasi hutan didapatkan hasil

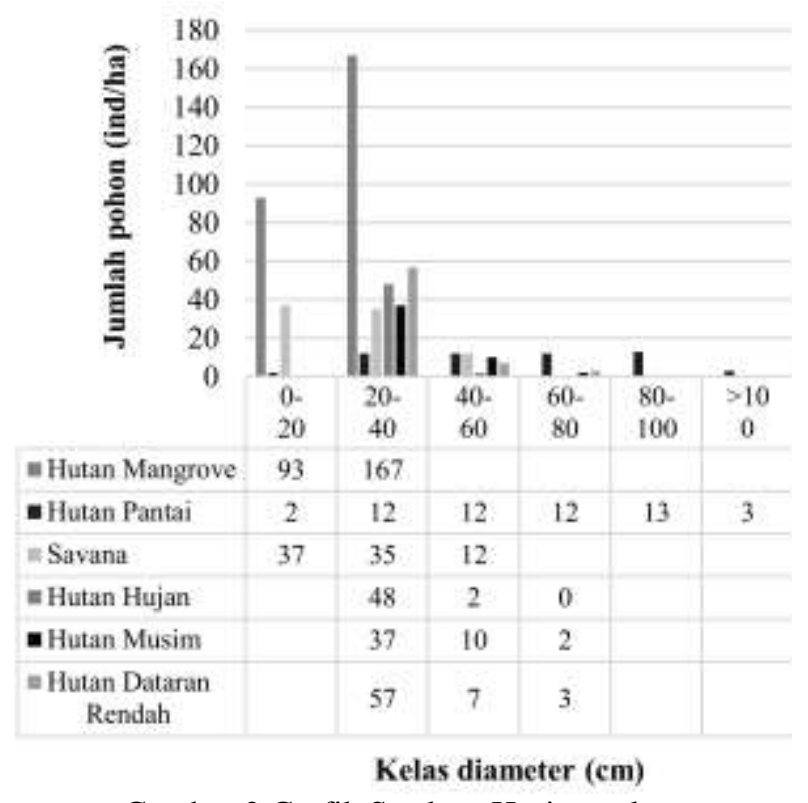

Gambar 2 Grafik Struktur Horizontal hutan pantai memiliki nilai terbesar yaitu $97.93 \mathrm{~m}^{2} / \mathrm{ha}$ sedangkan untuk nilai terendah yaitu berada di formasi hutan savana $5.47 \mathrm{~m}^{2} /$ ha (Gambar 4).

Hasil pengukuran LBDS yang didapatkan ini sangat berbeda dengan penelitian yang dilakukan oleh Anwar et al. (1984) di Pulau Siberut, dinyatakan bahwa pohon pohon yang memiliki diameter lebih dari $15 \mathrm{~cm}$ pada ketinggian dada di tujuh tipe hutan dataran rendah memiliki nilai sebesar 16-42 m/ha. Hasil perhitungan di formasi hutan dataran rendah dibaluran didapatkan hasil pehitungan melebihi pernyataan Anwar et al. (1984) sebesar $61.05 \mathrm{~m}^{2} /$ ha namun nilai ini masih lebih rendah jika dibandingkan dengan formasi hutan pantai. Luas bidang dasar (LBDS) yang didapatkan di hutan hujan juga memiliki nilai dibawah dari hutan pantai sebesar $59.81 \mathrm{~m} / \mathrm{ha}$. secara umum, seharusnya hutan hujan dan hutan dataran rendah seharusnya memiliki nilai LBDS yang lebih rapat. Beberapa faktor yang memengaruhi hal tersebut antara lain banyaknya ditemukan pohon yang tumbang dan aliran air yang menghambat pertumbuhan dan perkembangan dari pohon yang ada di formasi hutan hujan dan hutaran rendah.

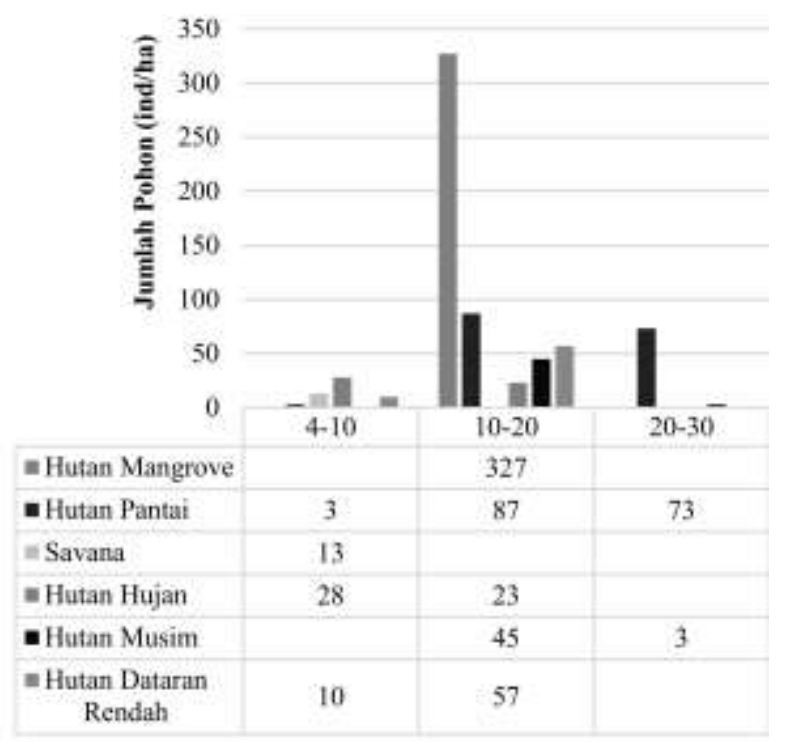

Kelas Tinggi (m)

Gambar 3 Grafik Struktur Vertikal

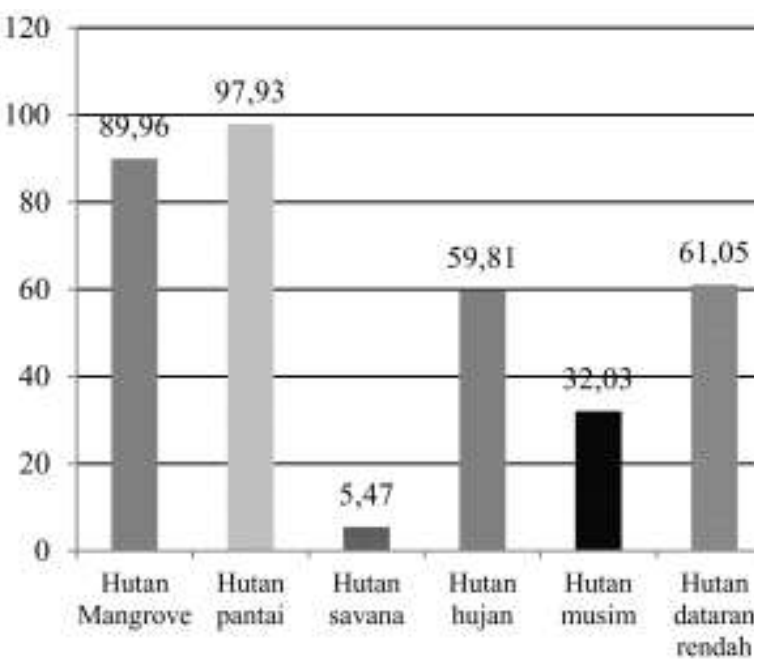

Gambar 4 Sebaran LBDS berbagai formasi hutan 


\section{SIMPULAN DAN SARAN}

\section{Simpulan}

Keragaman jenis tumbuhan tertinggi terdapat pada formasi hutan musim yaitu sebanyak 50 jenis. Jenis pohon yang mendominasi di setiap formasi hutan antara lain hutan mangrove yaitu $R$. apiculata, hutan pantai grewia eriocarpa, hutan savana yaitu Z.mauritiana, hutan hujan yaitu Streblus asper, hutan musim yaitu Schouthenia ovate dan untuk hutan dataran rendah didominasi oleh jenis grewia eriocarpa. Tingkat keanekaragaman jenis pada setiap formasi hutan tergolong dalam kategori rendah hingga sedang. Perbandingan Indeks kesamaan komunitas antar formasi hutan tergolong rendah $(<50 \%)$. Jumlah luas bidang dasar (LBDS) untuk tingkat pohon dan tiang di setiap formasi hutan didapatkan hasil hutan pantai memiliki nilai terbesar yaitu $97.93 \mathrm{~m}^{2} / \mathrm{ha}$ sedangkan untuk nilai terendah yaitu berada di formasi savana $5.47 \mathrm{~m}^{2} / \mathrm{ha}$.

\section{Saran}

Perlu dilakukan pemeliharaan dan pengawasan hutan yang lebih intensif untuk mencegah terjadinya kerusakan hutan lindung berbagai formasi hutan mengingat TN Baluran merupakan TN dengan kondisi ekosistem yang unik dan menjadi destinasi tujuan utama untuk wisata sehingga rentan akan faktor gangguan hutan.

\section{DAFTAR PUSTAKA}

Aksornkoae S. 1993. Ecology and Management of Mangrove. IUCN. Bangkok. Thailand Basuk

Anwar J, Damanik SJ , Hisyam N, Whitten AJ. 1984. Ekologi Ekosistem Sumatera. Yogyakarta (ID): Gadjah Mada University Press

Baluran National Park. 2014. Profil Taman Nasional Baluran. http://baluran-nationalpark.web.id. Diakses 22 November 2015.

Baluran National Park. 2014. Profil Taman Nasional Baluran. Balurannational park.web.id. Diakses pada Rabu, 18 November 2015.

Departemen Kehutanan. 2013. Profil Balai Besar Taman Nasional Bluran Situbondo Jawa Timur.
Direktorat Jendral Perlindung Hutan dan Konservasi Alam

Hilwan I. 2012. Komposisi jenis dan struktur tegakan pada areal bekas tebangan di PT Salaki Summa Sejahtera, Provinsi Sumatera Barat. Jurnal Silvikultur Tropika. 03(03): 155-16.

Indriyanto. 2012. Ekologi Hutan. Jakarta (ID): PT Bumi Aksara.

Irwan TD. 2009. Komposisi jenis dan struktur tegakan hutan di Taman Nasiona Gunung Ciremai, Jawa Barat [skripsi]. Bogor (ID): Institut Pertanian Bogor

Kusmana C, Susanti S. 2015. Komposisi dan struktur tegakan hutan alam di Hutan Pendidikan Gunung Walat, Sukabumi. Jurnal Silvikultur Tropika. 5(3):210-217.

Kusmana C. 1997. Metode Survey Vegetasi. Bogor: (ID). IPB Press.

Ludwig JA, Reynold JF. 1988. Statistikal Ecologi A Primer on Methods and Computing. USA, John Wiley \& Sons Inc

Magurran AE. 1988. Ecological Diversity and Its Measurement. London (EN): Croom Helm Ltd

Mueller-Dumbois D, Ellenberg H. 1974. Aims and Methods of Vegetation of Ecology. New York (US): Willey and Sons Inc

Mulyasana D. 2008. Kajian keanekaragaman jenis pohon pada berbagai ketinggian tempat di Taman Nasional Gunung Ciremai Propinsi Jawa Barat [skripsi]. Bogor (ID): Institut Pertanian Bogor.

Mulyana D, Kusmana C, Budi SW, Wasis B. 2017. Species and structure composition of nature disturbed forest stand in Papandayan Mountain, West Jawa Indonesia. IJSBAR. 31(2):286-296

Nursal, Fauziah, Ismiati, 2005. Struktur dan Komposisi Vegetasi Mangrove Tanjung Sekodi Kabupaten Bengkalis Riau. Jurnal Biogenesis 2(1): 1-7.

Oladoye AO, Aduradola AM, Adedire MO, Agboola DA. 2014. Composition and stand structure of regenerating tropical rainforest ecosystem in South-western Nigeria. Internasional Journal of Biodiversity and Conservation. 6(11): 765-776

Soerianegara I. Indrawan A. 2002. Ekologi Hutan Indonesia. Bogor (ID): Laboratorium Ekologi Hutan, Fakultas Kehutanan, Institut Pertanian Bogor

Tomlinson PB. 1986. The Botany of Mangrove. Cambridge (EN). Cambridge University Press. 
Lampiran 1 Daftar jenis tumbuhan dengan nilai INP tertinggi berbagai formasi hutan

\begin{tabular}{|c|c|c|c|c|}
\hline No & Formasi Hutan & Tingkat Pertumbuhan & Nama Jenis & $\operatorname{INP}(\%)$ \\
\hline \multirow[t]{6}{*}{1} & Hutan Mangrove & Semai \& Tumbuhan Bawah & - & \\
\hline & & Pancang & Rhizophora stylosa & 81.03 \\
\hline & & & Rhizophora apiculata & 68.21 \\
\hline & & & Ceripos tagal & 35.64 \\
\hline & & Pohon & Rhizophora stylosa & 216.35 \\
\hline & & & Rhizophora apiculata & 83,65 \\
\hline \multirow[t]{12}{*}{2} & Hutan Pantai & Semai \& Tumbuhan Bawah & Optismenus bermanni & 36,29 \\
\hline & & & Wedelia trilobata & 30,31 \\
\hline & & & Ipomoea obscura & 23,50 \\
\hline & & Pancang & Corypha utan & 106,58 \\
\hline & & & Grewia eriocarpa & 29,55 \\
\hline & & & Anomianthus dulcis & 22,54 \\
\hline & & Tiang & Grewia eriocarpa & 110,00 \\
\hline & & & Schleichera oleosa & 69,30 \\
\hline & & & Syzygium polyanthum & 43,17 \\
\hline & & Pohon & Salmalia valetonii & 70.51 \\
\hline & & & Protium javanicum & 61.43 \\
\hline & & & Heritiera litoralis & 42.86 \\
\hline \multirow[t]{8}{*}{3} & Hutan Savana & Semai \& Tumbuhan Bawah & Brachiaria reptans & 24.58 \\
\hline & & & Eleusine indica & 21.40 \\
\hline & & & Eragrosis amabilis & 20.42 \\
\hline & & Pancang & Ziziphus mauritiana & 200 \\
\hline & & Tiang & Azadirachta indica & 68.97 \\
\hline & & & Ziziphus mauritiana & 31.02 \\
\hline & & Pohon & Ziziphus mauritiana & 269.60 \\
\hline & & & Azadirachta indica & 30.40 \\
\hline \multirow[t]{12}{*}{4} & Hutan Hujan & Semai \& Tumbuhan Bawah & Anomianthus dulcis & 37.30 \\
\hline & & & Chromolaena odorata & 28.57 \\
\hline & & & Bauhinia scandens & 25.79 \\
\hline & & Pancang & Kleinhovia hospita & 65.00 \\
\hline & & & Capparis micracantha & 32.50 \\
\hline & & & Anomianthus dulcis & 22.50 \\
\hline & & Tiang & Streblus asper & 101.12 \\
\hline & & & Protium jaavanicum & 97.93 \\
\hline & & & Aleurites moluccana & 75 \\
\hline & & Pohon & Streblus asper & 153.54 \\
\hline & & & Protium Javanicum & 34.40 \\
\hline & & & Cissus repens & 31.16 \\
\hline \multirow[t]{12}{*}{5} & Hutan Musim & Semai \& Tumbuhan Bawah & Optismenus burmanni & 36,38 \\
\hline & & & Ageratum conyzoides & 27,70 \\
\hline & & & Cosmos sp & 25,73 \\
\hline & & Pancang & Schouthenia ovata & 48,20 \\
\hline & & & Grewia eriocarpa & 39,38 \\
\hline & & & Schleichera oleosa & 32,09 \\
\hline & & Tiang & Schouthenia ovata & 179,14 \\
\hline & & & Grewia eriocarpa & 41,61 \\
\hline & & & Acacia leucophloea & 35,67 \\
\hline & & Pohon & Tamarindus indica & 79,00 \\
\hline & & & Schouthenia ovata & 68,87 \\
\hline & & & Schleichera oleosa & 51,69 \\
\hline \multirow[t]{12}{*}{6} & Hutan Dataran Rendah & Semai \& Tumbuhan Bawah & Acalypha indica & 31,50 \\
\hline & & & Lantana camara & 25,39 \\
\hline & & & indigofera sumatrana & 27,69 \\
\hline & & Pancang & Microcos tomentosa & 141,6 \\
\hline & & & Azadirachta indica & 29,16 \\
\hline & & & Grewia eriocarpa & 29,16 \\
\hline & & Tiang & Grewia eriocarpa & 160,55 \\
\hline & & & Schoutenia ovata & 57,47 \\
\hline & & & Schleichera oleosa & 39,16 \\
\hline & & Pohon & Grewia eriocarpa & 145,54 \\
\hline & & & Schleichera oleosa & 69,52 \\
\hline & & & Microcos tomentosa & 53,59 \\
\hline
\end{tabular}

